\title{
Determination of Bispyribac Sodium $10 \%$ SC (Herbicide) Residue Level in Straw, Grain and Soil Using HPLC Method
}

\author{
C. Tamilselvan*, S. John Joseph, V. Angayarkanni \\ Bioscience Research Foundation, Porur, Chennai - 600 116, Tamil Nadu, India \\ E-mail address: brfchennai@gmail.com
}

\begin{abstract}
A field trial was conducted to evaluate the residues of Bispyribac sodium $10 \% \mathrm{SC}$ on rice crop during Kharif season 2013 at Kandikai in Thiruvallur District, Tamilnadu, India. Randomized block design was followed withthree treatments forthree replicates. Bispyribac sodium $10 \%$ SC $200 \mathrm{~g}$ a.i./ha, $500 \mathrm{~g}$ a.i./ha and control (water spray) was sprayed using hand operated Maax battery sprayer with a spray volume of 300 litres per hectare at 15 days after transplantation of rice crop (ADT 45). At harvest, samples of grain, straw and soil were collected replicate wise from each treatment along with the control. These samples were stored in icebox and transfer to the laboratory under cooled condition for analysis.All the residues samples were analyzed for Bispyribac sodium content by a validated HPLC method at the minimum detectable concentration of $0.01 \mathrm{ppm}$. The result revealed that no detectable level of Bispyribac sodium in straw, grain and soil at harvest. Thepost treatmentand preharvest intervalwas 60 days after transplantation.
\end{abstract}

Keywords: Bispyribac Sodium; Herbicide; Residue; Straw; Grain; Soil and High performance liquid chromatography

\section{INTRODUCTION}

Pesticides acted as the most widely used form of chemical in agriculture. They are used to kill any undesired organism interfering with agricultural production. A pesticide is a chemical or biological agent to control organisms that are considered to be harmful [1].

Pesticides are categorized into four main categories which are herbicides, fungicides, insecticides and rodenticides. Target pests can include insects, plants pathogen, weeds, mollusks, birds, mammals, and fish nematodes (roundworm) that destroy disease spreading properties or vectors for diseases. Although the use of pesticides is for human benefits, some have weaknesses such as potential toxicity to human and other animals. Over dose of pesticide cause soil contamination and undegradedpesticides remain as a residue in the soil $[2]$.

Herbicide is the type of pesticide used to kill unwanted plants and weeds. Selective herbicides kill specific targets, while leaving the non-targeted planted crop without giving any harm. Herbicides are commonly used in agricultural production system throughout the world and Indian plantations are no exception. 
The efficacy of herbicide in controlling weeds is important, its residual impact should also be considered for environmental safety for all processes which include soil adsorption, breakdown and degradation. The most of the soil-bound pesticides are due to adsorption of soil particles [3]. Transfer in soil is the movement of pesticide downward and spreading away from the target plants [4].

The objectives of the research are to determine residue of Bispyribac sodium which is newer herbicide widely used in agriculture for control major weeds in the rice crop. This research also aims to standardize and develop HPLC method for determination of Bispyribac sodium residues and their extraction, isolation and purificationmethod in rice straw, grain and soil samples.

\section{MATERIALS AND PREPARATION}

Solvents (acetonitrile,silver nitrate, phosphoric acid and reference standard Bispyribac sodium) and HPLC water used for this study were Sigma Aldrich and Merck respectively.

\section{1. Instrumentation and analytical conditions}

HPLC analyses were performed using the LC-10AT VP and SPD-10A UV-VIS Detector of Shimadzu with PC integrator. A reversed-phase column (Qualisil BDS 5u C18, Size-250 x $4.6 \mathrm{~mm}$ (i.d); particle size $5 \mu \mathrm{m}$ ) was used. The room temperature was maintained at $32{ }^{\circ} \mathrm{C}$. The mobile phase was a mixture of $0.1 \%$ phosphoric acid: Acetonitrile $(1: 1)$ with a flow rate of $1.0 \mathrm{~mL} / \mathrm{min}$. at $248 \mathrm{~nm}$.

\section{2. SamplePreparation Procedure}

\section{2. 1. Sample Preparation Straw:}

About $2 \mathrm{~kg}$ of straw was collected from each replication and cut into small pieces, mixed thoroughly by the method of cone and quartering and rejecting the opposite ends. The sample of $500 \mathrm{~g}$ was taken to the laboratory in icebox and stored indeep freezer until analysis.

\section{2. 2. Sample Preparation Grain}

At harvest $2 \mathrm{~kg}$ of grain was collected after threshing from each replication and mixed thoroughly by the method of cone and quartering and rejecting the opposite ends. The sample $500 \mathrm{~g}$ was taken to the laboratory in icebox and stored in deep freezer until analysis.

\section{2. 3. Sample Preparation Soil}

About $1 \mathrm{~kg}$ of soil was collected during harvest $(0-15 \mathrm{~cm})$ in 10 locations using soil auger and removed unwanted roots and debris from soil. After thorough mixing $500 \mathrm{~g}$ of sample was collected with quartering technique. The samples were packed in polyethylene bags with clear identification mark and taken to the laboratory in icebox and stored in deep freezer until analysis.

\section{2. 4. Reference Standard Preparation}

A known weight of standard accurately was taken in $100 \mathrm{ml}$ standard flask. Added sufficient volume of Acetonitrile, mixed well and made to the mark on the standard flask using the same solvent after dissolved the content completely. Allowed the standard solution 
to stand for 30 minutes at room temperature for equilibration. Stored in deep freezer and necessary dilutions were made from the stock whenever required.

\section{2. 5. Sample Storage}

Stored the samples as such or if the bulk is too much, after the preparation of the sample. Depending upon the nature of the sample, keep the samples or their extracts either in deep freezer at $15{ }^{\circ} \mathrm{C}$ or in refrigerator until taken up for analysis. Ensure that the samples do not absorb or lose moisture during storage. Avoid undue long storage periods.

\section{METHOD OF ANALYSIS}

\section{1. Extraction of Straw and Grain}

Exactly $50 \mathrm{~g}$ of representative sample was taken in a high speed blender; add $2 \mathrm{ml}$ of $0.1 \mathrm{~N}$ silver nitrate solution and $25 \mathrm{ml}$ mixture of $0.1 \%$ phosphoric acid: Acetonitrile $(1: 1)$ solutions were added. Then it was homogenized for 2 minutes. The homogenized sample was extracted with $100 \mathrm{ml}$ of methanol. Extraction process was done on an end-over-end mechanical shaker for a period of 15 minutes. Extract was filtered through whattman filter paper. The extraction process was repeated twice with the $75 \mathrm{ml}$ of solvent after adding add 2 $\mathrm{ml}$ of $0.1 \mathrm{~N}$ silver nitrate solution and $25 \mathrm{ml}$ mixture of $0.1 \%$ phosphoric acid: Acetonitrile (1:1) solutions were added. The combined filtrate was concentrated to approximately $5 \mathrm{ml}$ of volume using rotary vacuum evaporator at temperature of $40^{\circ} \mathrm{C}$.

\section{2. Extraction of Soil}

Exactly $50 \mathrm{~g}$ of representative sample was taken in a high speed blender; add $2 \mathrm{ml}$ of $0.1 \mathrm{~N}$ silver nitrate solution and $25 \mathrm{ml}$ mixture of $0.1 \%$ phosphoric acid: Acetonitrile (1:1) solutions were added. Then it was homogenized for 2 minutes. The homogenized sample was extracted with $100 \mathrm{ml}$ of methanol. Extraction process was done on an end-over-end mechanical shaker for a period of 15 minutes. Extract was filtered through whattman filter paper. The extraction process was repeated twice with the $75 \mathrm{ml}$ of solvent after adding add 2 $\mathrm{ml}$ of $0.1 \mathrm{~N}$ silver nitrate solution and $25 \mathrm{ml}$ mixture of $0.1 \%$ phosphoric acid: Acetonitrile $(1: 1)$ solutions were added. The combined filtrate was concentrated to smaller volume $(5 \mathrm{ml})$ using rotary vacuum evaporator at temperature of $40^{\circ} \mathrm{C}$.

\section{3. Calibration details}

Different known concentrations of Bispyribac sodium $(0.01,0.1,0.5,1.0,1.5,2.0 \& 2.5$ ppm) were prepared in mobile phase by diluting the stock solution. Injected $20 \mu 1$ of standard solution and the peak area resulting from the elution of compound strictly adhering to absorbance of peak retention was measured. A calibration curve has been plotted for concentration of the standards injected versus area observed and the curve was found linear up to the lowest concentration range $0.01 \mathrm{ppm}$. Thecalibration chart details are presented in the Figure 1 given below. 


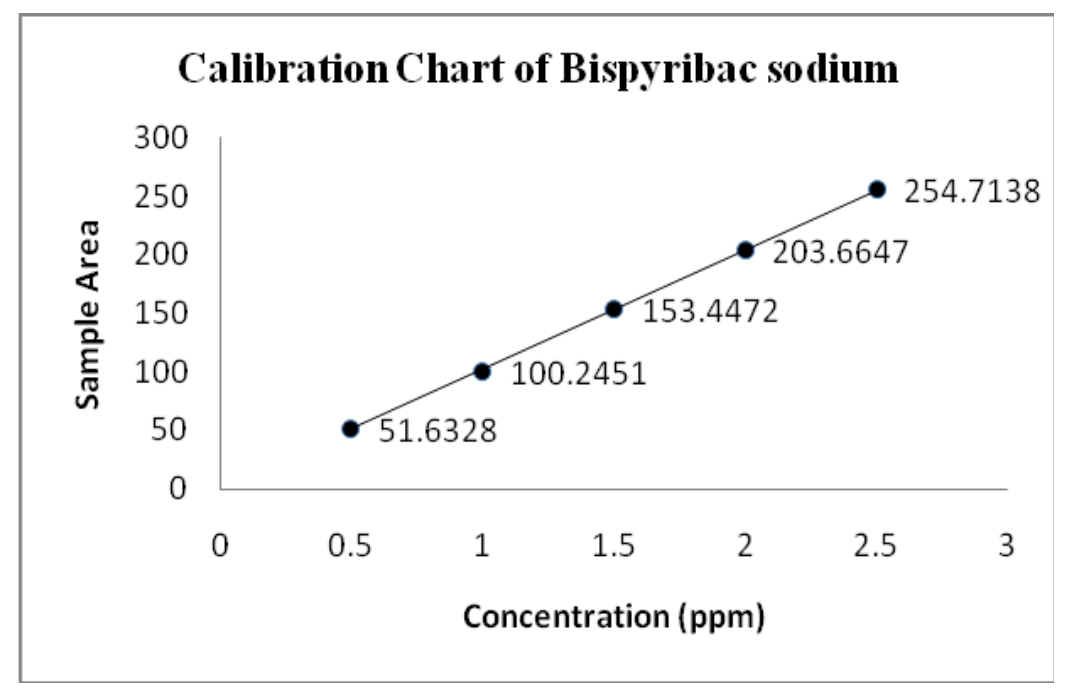

Figure 1. Calibration chart of Bispyribac sodium concentration Vs peak area.

\section{4. Recovery}

\section{Preparation of fortified standard solutions:}

Bispyribac sodium was prepared taken in to three separate $100 \mathrm{ml}$ standard flasks and added sufficient volume of mobile phase to dissolve the contents. To this fortified three levels of standards $0.5,1.0,1.5 \mathrm{ppm}$ respectively. Made the standard flasks up to the mark-using Mobile phase and mixed well. The standard solution of $20 \mu \mathrm{l}$ was injected in the HPLC system continuously and recorded the respective peak areas (Table 1,2 and 3). The typical HPLC chromatogram of fortified and blank samples of straw, grain and soil were presented in Figures 2 to 7.

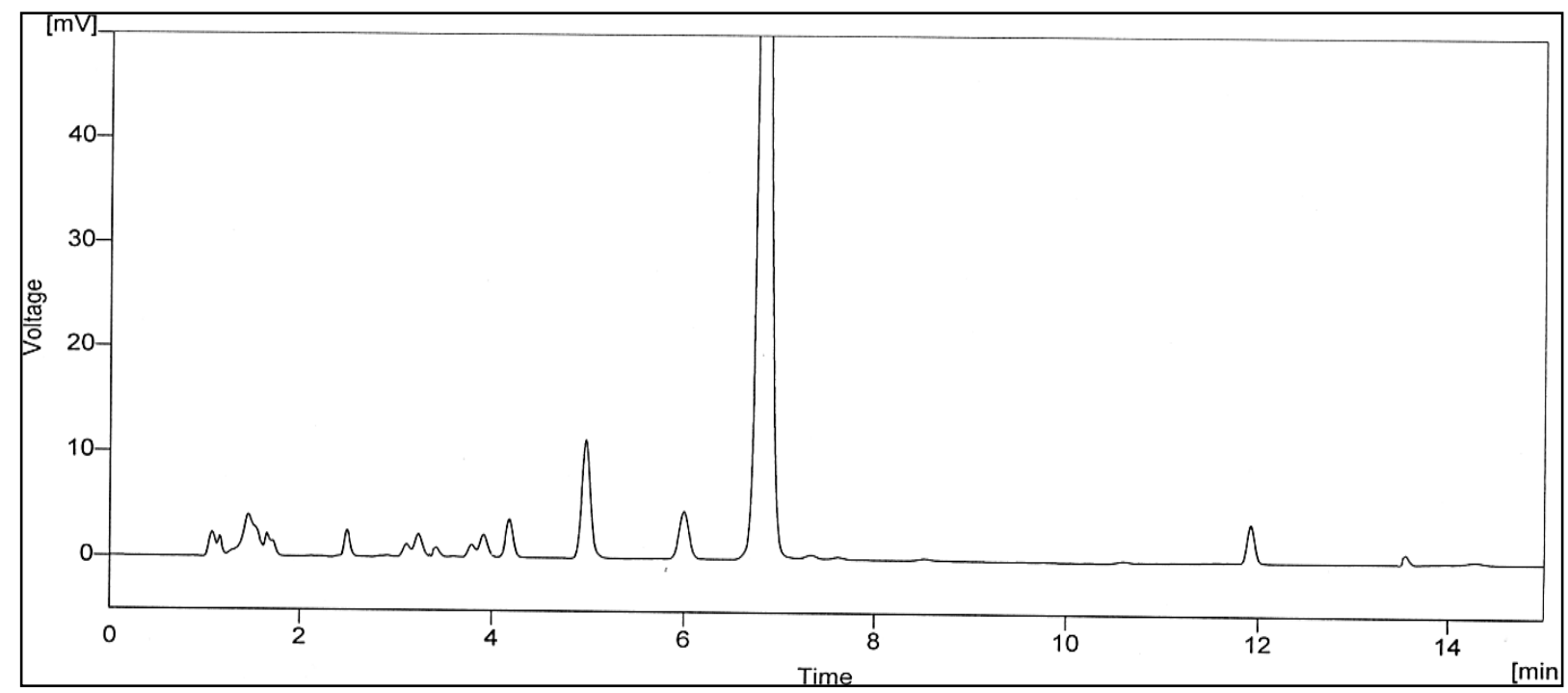

Figure 2. Typical HPLC chromatogram of Rice straw sample-Blank. 


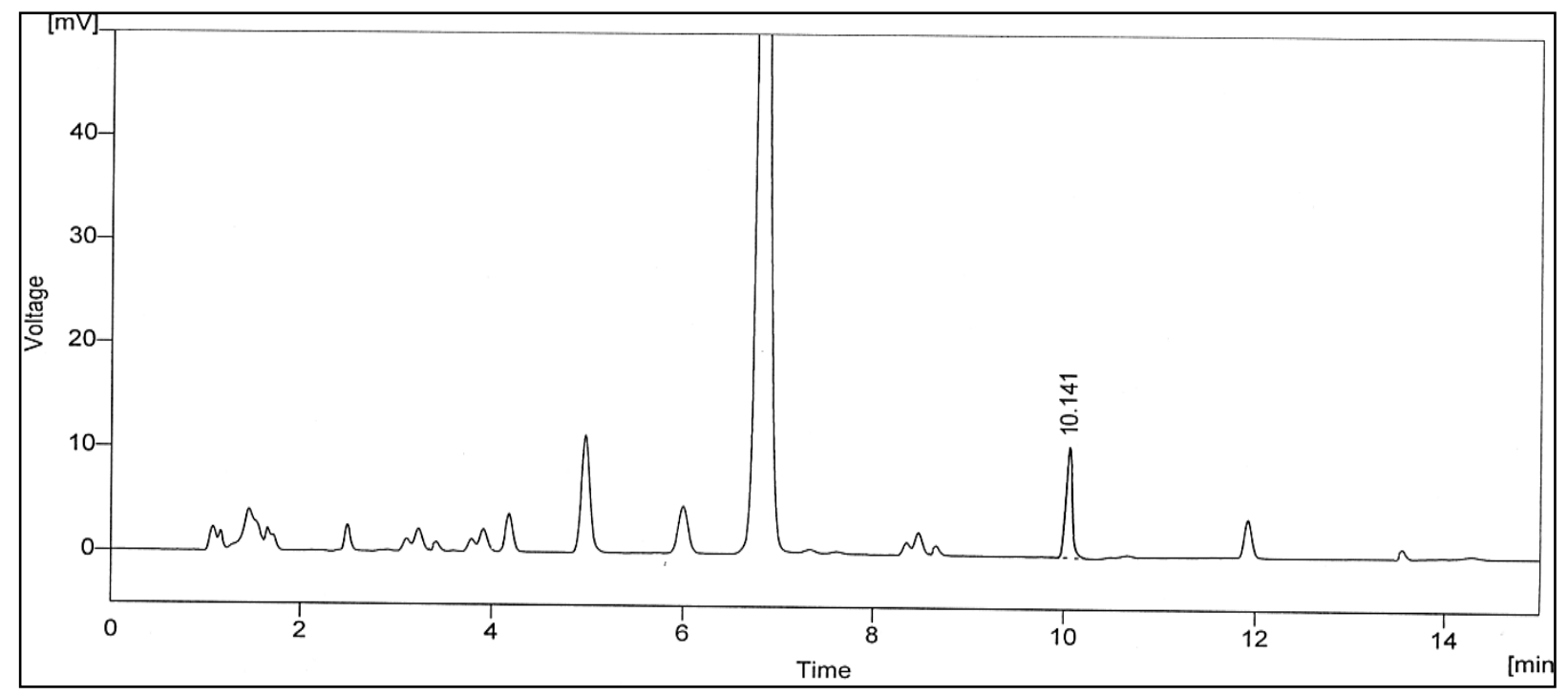

Figure 3. Typical HPLC chromatogram of Rice straw sample-Fortified.

Table 1. Recovery of Straw.

\begin{tabular}{|c|c|c|c|}
\hline $\begin{array}{c}\text { Fortified } \\
\text { Concentration (ppm) }\end{array}$ & $\begin{array}{c}\text { Fortified Area } \\
(\mathbf{m V} \cdot \text { Sec) }\end{array}$ & Recovery (\%) & \multirow{2}{*}{ Mean \pm SD } \\
\hline 0.5 & 49.7352 & 95.84 & \multirow{2}{*}{$96.06 \pm 0.27$} \\
\cline { 1 - 3 } 1.0 & 97.4805 & 96.04 & \\
\hline 1.5 & 149.4826 & 96.38 & \\
\hline
\end{tabular}

Table 2. Recovery of Grain.

\begin{tabular}{|c|c|c|c|}
\hline $\begin{array}{c}\text { Fortified } \\
\text { Concentration (ppm) }\end{array}$ & $\begin{array}{c}\text { Fortified Area } \\
(\mathbf{m V} \cdot \text { Sec) }\end{array}$ & Recovery (\%) & Mean \pm SD \\
\hline 0.5 & 49.1489 & 96.64 & \multirow{2}{*}{$97.01 \pm 0.39$} \\
\cline { 1 - 3 } 1.0 & 96.7483 & 96.97 & \\
\hline 1.5 & 148.3946 & 97.43 & \\
\hline
\end{tabular}

Table 3. Recovery of Soil.

\begin{tabular}{|c|c|c|c|}
\hline $\begin{array}{c}\text { Fortified } \\
\text { Concentration (ppm) }\end{array}$ & $\begin{array}{c}\text { Fortified Area } \\
(\mathbf{m V} \cdot \text { Sec) }\end{array}$ & Recovery (\%) & Mean \pm SD \\
\hline 0.5 & 50.2639 & 97.76 & \multirow{2}{*}{$98.10 \pm 0.33$} \\
\hline 1.0 & 97.6953 & 98.13 & \\
\hline 1.5 & 147.1898 & 98.42 & \\
\hline
\end{tabular}




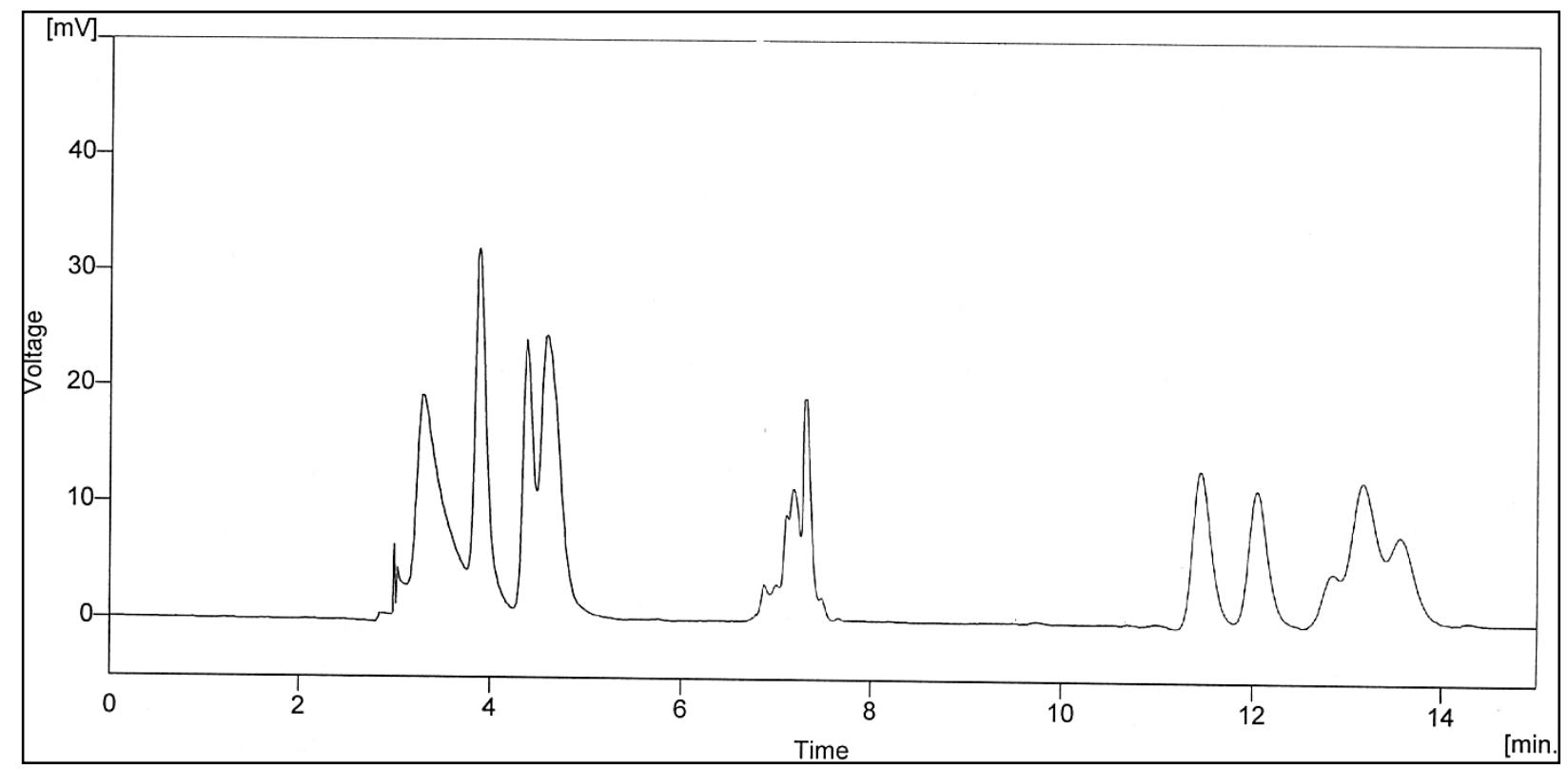

Figure 4. Typical HPLC chromatogram of Rice grain sample-Blank.

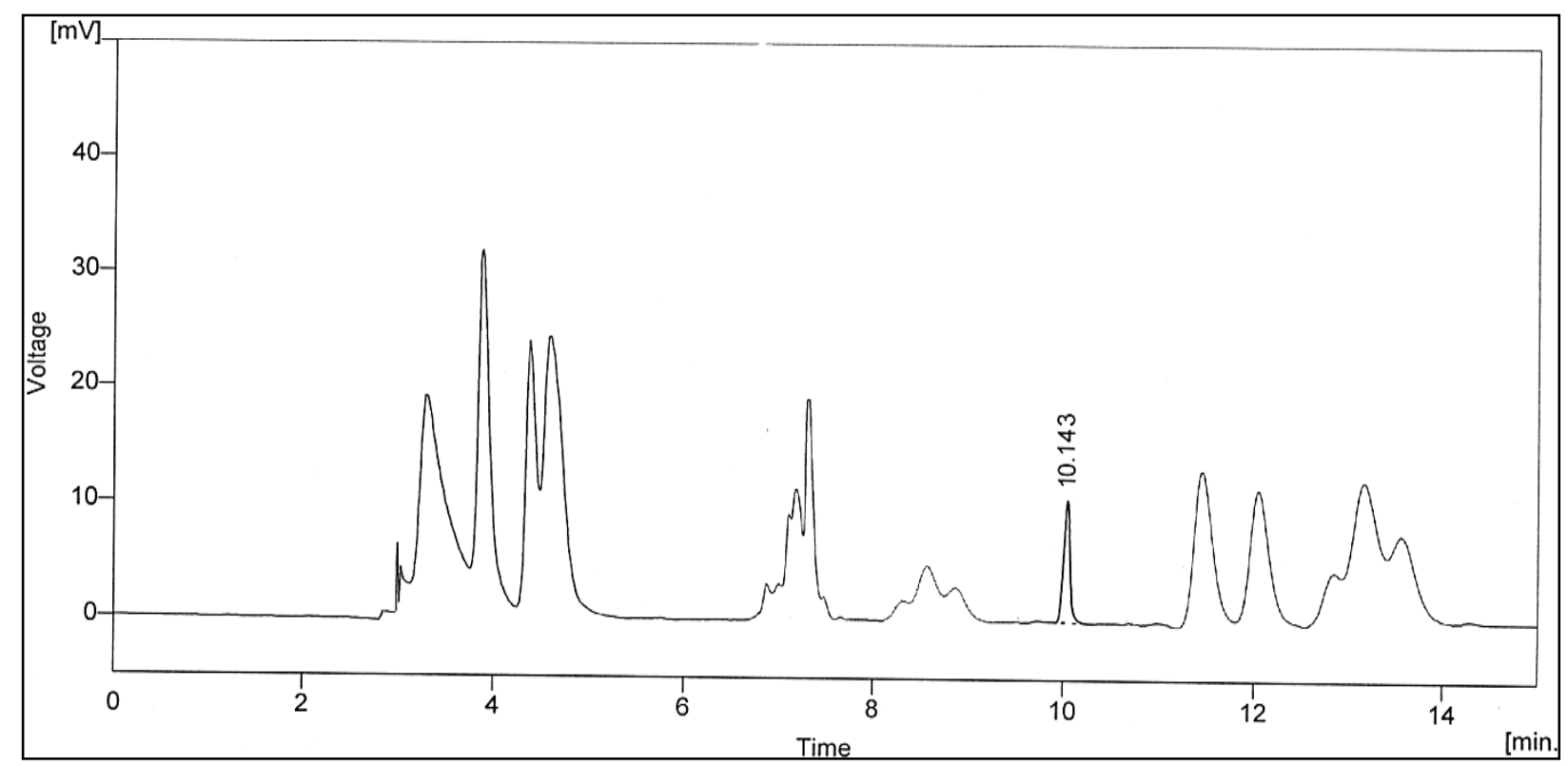

Figure 5. Typical HPLC chromatogram of Rice grain sample-Fortified. 


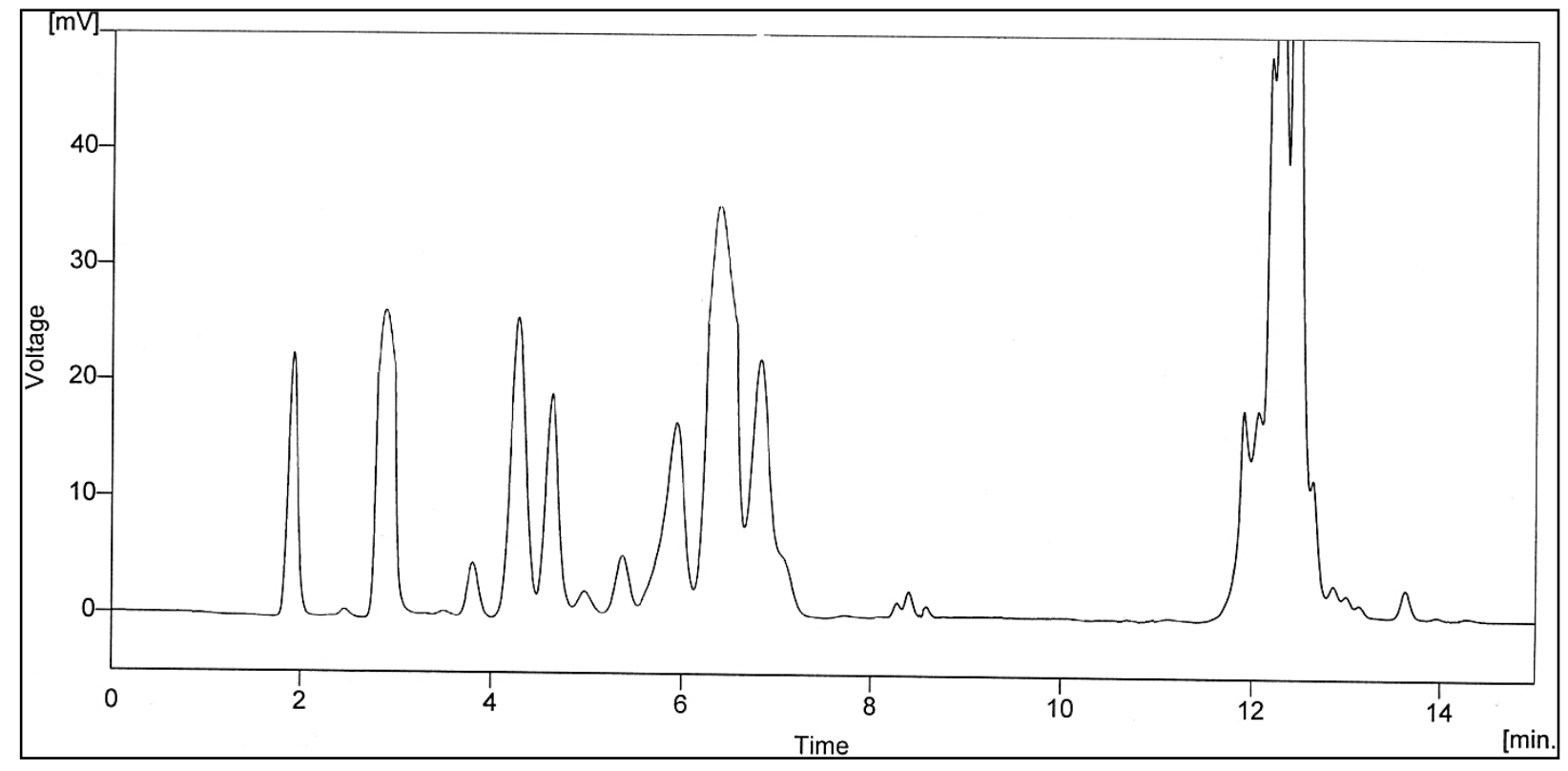

Figure 6. Typical HPLC chromatogram of Soil sample-Blank.

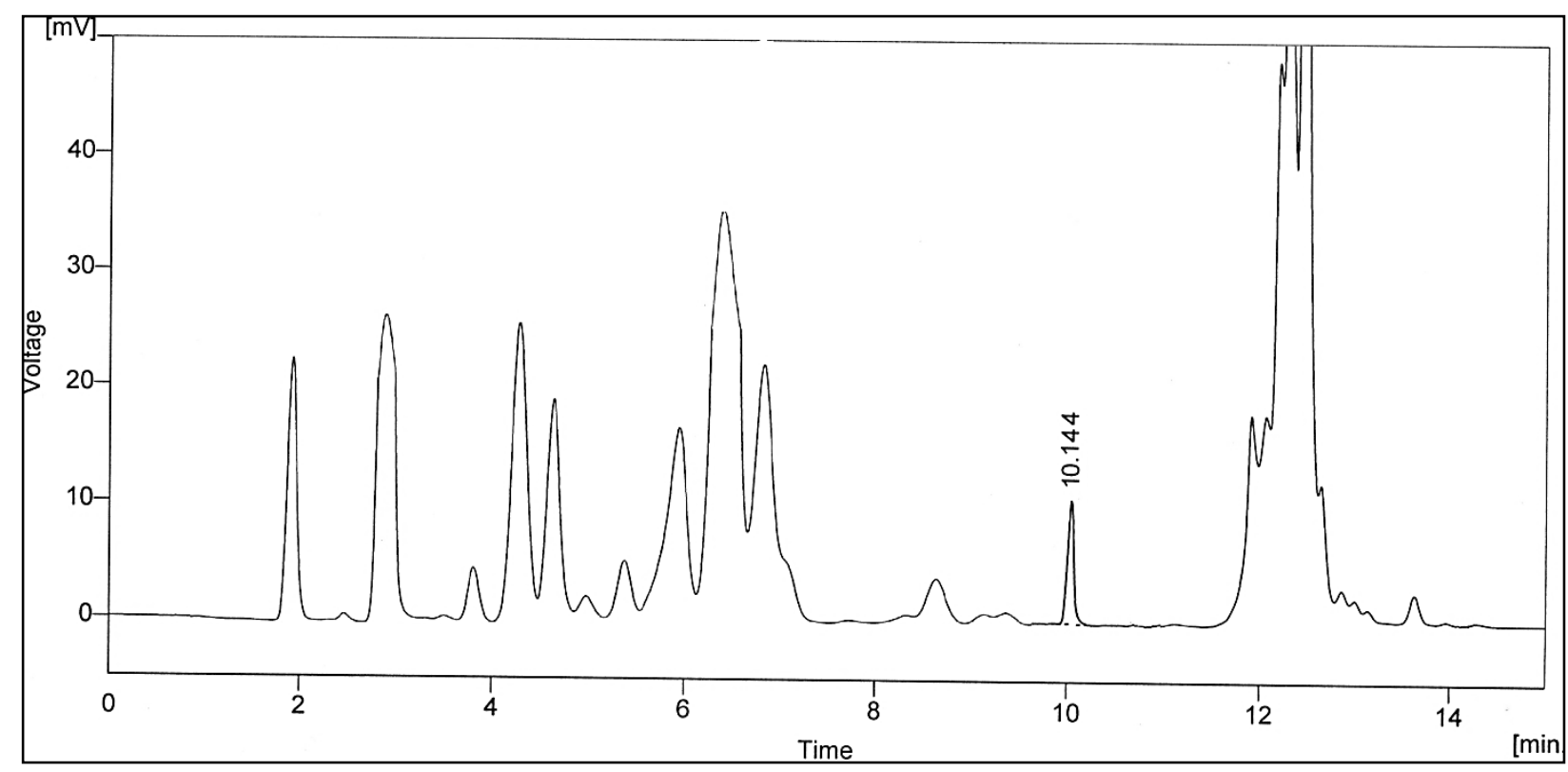

Figure 7. Typical HPLC chromatogram of Soil sample-Fortified.

\section{RESULTS AND DISCUSSION}

A field trial was conducted at Kandikai in Thiruvallur District, Tamilnadu, India to evaluate the residues of Bispyribac sodium $10 \% \mathrm{SC}$ on rice cropduring Kharif season 2013. A randomized block design was followed with three replicates for three treatments. Bispyribac sodium $10 \%$ SC @ $200 \mathrm{~g}$ a.i./ha, $500 \mathrm{~g}$ a.i./ha and water spray served as a control. After15 day's form the transplantation spraying was carried out by hand operated Maax battery sprayer with a spray volume of 300 litres per hectare. Rice variety 'ADT 45' 
was grown in a net area of $25 \mathrm{sq} \cdot \mathrm{m}$ per replication. The local agriculture practice of using as fertilizer and other plant production chemical was applied twice as per recommended dosage. The water was irrigated daily wise up to harvest andit wasstopped before 5 days of harvest. At harvest samples of grain, straw and soil was collected replication wise from each treatment along with the control. The analyses of result revealed that no Bispyribac sodium residues could be deducted in straw, grain and soil at harvest in all treatment. The post treatment and pre-harvest interval was 60 days (Table 5, 6 and 7).

The validated HPLC method clearly indicated thatthe present method of the investigation is recommended for reduce analysis of any commodities. The validation is reflected the linearity, precision and accuracy which are very acceptable limit and high resolution without interference of matrix up to $<0.01 \mathrm{ppm}$ level (Figure 1).

The method validation ensures analyses creditability. In this study the parameters precision, linearity, accuracy, limit of detection (LOD) and limit of quantification (LOQ) were adopted.

\section{1. Linearity}

For all method calibration curve were prepared on single day. The result obtained was plotted in the linear regression curve shown Figure 1. The curves are linear and gradually slope. The intercept and correlation coefficient is found to be 0.99 .

The standard solution of Bispyribac sodium injected using HPLC modelLC-10AT VP and SPD-10A UV-VIS Detector of Shimadzu. A reversed-phase column (Qualisil BDS 5u $\mathrm{C} 18$, Size- $250 \times 4.6 \mathrm{~mm}$ (i.d); particle size $5 \mu \mathrm{m}$ ) was used. The mobile phase was a mixture of $0.1 \%$ phosphoric acid: Acetonitrile (1:1) with a flow rate of $1.0 \mathrm{~mL} / \mathrm{min}$ and the elute was monitored at the wavelength of $248 \mathrm{~nm}$. The column was maintained at atemperature of 25 ${ }^{\circ} \mathrm{C}$. The retention time and peak area of the test substance were recorded at $10.14 \mathrm{~min}$. The calibration curve for the HPLC analyses was conducted by plotting the peak area of normalization of Bispyribac sodium on $\mathrm{Y}$-axis against concentration $\mathrm{X}$-axis the obtained was shown in Figure 1. The peak a curve is straight line and linear.

\section{2. Precision}

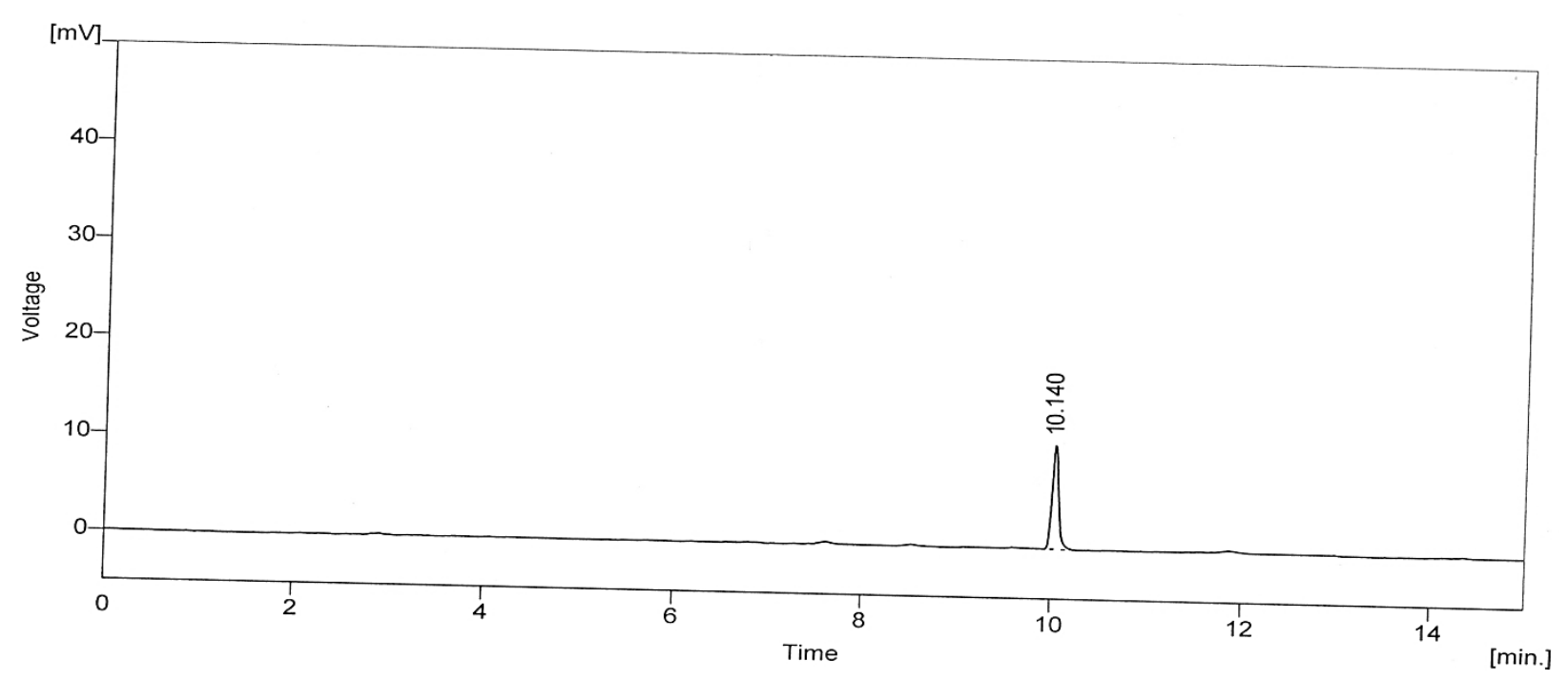

Figure 8. The peak area for Bispyribac sodium standards solution. 
The intra-day precision method was repeated for analyses at three concentration levels. The RSD values clearly showed that variation was very minimal and accurate value of the respective concentration was obtained. The accuracy of an analytical method is the absence of test result true value which clearly reflected the recovery result. The mean recovery of straw, grain and soil were 96.06, 97.01 and 98.10 respectively (Table 1, 2 and 3).

Table 4. Summarization of Bispyribac sodium Standard Solution Data of HPLC.

\begin{tabular}{|c|c|c|}
\hline Standard Solution & Retention time & Peak Area \\
\hline $\begin{array}{c}\text { Bispyribac sodium Standard } \\
\text { Solution }\end{array}$ & 10.140 & 52.8199 \\
\hline
\end{tabular}

The chromatogram in Figure 8 showed the peak area for Bispyribac sodium standard solution containing Bispyribac sodium as the active ingredient. The peak on retention time was 10.140, which matched with the retention time of Bispyribac sodium compound; hence the standard solution was confirmed to contain certain level of Bispyribac sodium concentration. Table 4 summarized the peak area and retention time of Bispyribac sodium standard solution. The residue determination of Bispyribac sodium $10 \% \mathrm{SC}$ content in rice straw, grain and soil are presented in Table 5, 6 and 7.

Table 5. Residue Determination of Bispyribac sodium 10\% SC Content in Rice Straw.

\begin{tabular}{|c|c|c|c|c|}
\hline Treatment & $\begin{array}{l}\text { Volume of the } \\
\text { sample (ml) }\end{array}$ & $\begin{array}{c}\text { Peak area of } \\
\text { Bispyribac sodium } \\
\text { in sample }\end{array}$ & $\begin{array}{c}\text { Bispyribac } \\
\text { sodium content } \\
(\mathrm{ppm})\end{array}$ & $\begin{array}{c}\text { Average of } \\
\text { Bispyribac } \\
\text { sodium content } \\
\text { (ppm) }\end{array}$ \\
\hline T1R1 & 5 & ND & $<0.01$ & \multirow{3}{*}{$<0.01$} \\
\hline T1R2 & 5 & ND & $<0.01$ & \\
\hline T1R3 & 5 & ND & $<0.01$ & \\
\hline $\mathrm{T} 2 \mathrm{R} 1$ & 5 & ND & $<0.01$ & \multirow{3}{*}{$<0.01$} \\
\hline $\mathrm{T} 2 \mathrm{R} 2$ & 5 & ND & $<0.01$ & \\
\hline T2R3 & 5 & ND & $<0.01$ & \\
\hline T3R1 & 5 & ND & $<0.01$ & \multirow{3}{*}{$<0.01$} \\
\hline T3R2 & 5 & ND & $<0.01$ & \\
\hline T3R3 & 5 & ND & $<0.01$ & \\
\hline
\end{tabular}

$\mathrm{ND}=$ Non-detectable $(<0.01 \mathrm{ppm})$ 
Table 6. Residue Determination of Bispyribac sodium $10 \%$ SC Content in Rice Grain.

\begin{tabular}{|c|c|c|c|c|}
\hline Treatment & $\begin{array}{l}\text { Volume of the } \\
\text { sample (ml) }\end{array}$ & $\begin{array}{c}\text { Peak area of } \\
\text { Bispyribac sodium } \\
\text { in sample }\end{array}$ & $\begin{array}{c}\text { Bispyribac } \\
\text { sodium content } \\
(\mathrm{ppm})\end{array}$ & $\begin{array}{c}\text { Average of } \\
\text { Bispyribac } \\
\text { sodium content } \\
(\mathrm{ppm})\end{array}$ \\
\hline T1R1 & 5 & ND & $<0.01$ & \multirow{3}{*}{$<0.01$} \\
\hline T1R2 & 5 & ND & $<0.01$ & \\
\hline T1R3 & 5 & ND & $<0.01$ & \\
\hline $\mathrm{T} 2 \mathrm{R} 1$ & 5 & ND & $<0.01$ & \multirow{3}{*}{$<0.01$} \\
\hline $\mathrm{T} 2 \mathrm{R} 2$ & 5 & ND & $<0.01$ & \\
\hline $\mathrm{T} 2 \mathrm{R} 3$ & 5 & ND & $<0.01$ & \\
\hline T3R1 & 5 & ND & $<0.01$ & \multirow{3}{*}{$<0.01$} \\
\hline T3R2 & 5 & ND & $<0.01$ & \\
\hline T3R3 & 5 & ND & $<0.01$ & \\
\hline
\end{tabular}

$\mathrm{ND}=$ Non-detectable $(<0.01 \mathrm{ppm})$

Table 7. Residue Determination of Bispyribac sodium $10 \%$ SC Content in Soil Residue.

\begin{tabular}{|c|c|c|c|c|}
\hline Treatment & $\begin{array}{l}\text { Volume of the } \\
\text { sample }(\mathrm{ml})\end{array}$ & $\begin{array}{c}\text { Peak area of } \\
\text { Bispyribac sodium } \\
\text { in sample }\end{array}$ & $\begin{array}{c}\text { Bispyribac } \\
\text { sodium content } \\
(\mathrm{ppm})\end{array}$ & $\begin{array}{c}\text { Average of } \\
\text { Bispyribac } \\
\text { sodium content } \\
\text { (ppm) }\end{array}$ \\
\hline T1R1 & 5 & ND & $<0.01$ & \multirow{3}{*}{$<0.01$} \\
\hline T1R2 & 5 & ND & $<0.01$ & \\
\hline T1R3 & 5 & ND & $<0.01$ & \\
\hline T2R1 & 5 & ND & $<0.01$ & \multirow{3}{*}{$<0.01$} \\
\hline $\mathrm{T} 2 \mathrm{R} 2$ & 5 & ND & $<0.01$ & \\
\hline T2R3 & 5 & ND & $<0.01$ & \\
\hline T3R1 & 5 & ND & $<0.01$ & \multirow{3}{*}{$<0.01$} \\
\hline T3R2 & 5 & ND & $<0.01$ & \\
\hline T3R3 & 5 & ND & $<0.01$ & \\
\hline
\end{tabular}




\section{CONCLUSION}

The residue analysis from the HPLC result showsthat Bispyribac sodium could not be deducted in straw, grain and soil at harvest $(<0.01 \mathrm{ppm})$. The post treatment and pre-harvest interval was 60 days after transplantation. Hence no residues found in rice crop and well below the allowable limit $(0.01 \mathrm{ppm})$. The Bispyribac sodium standard and fortified samplechromatogram clearly indicate that the absence of matrixinterference in the retention time of the substance and uniform retention time. From the result it is concluded,the developed method was clearly indicates that it is simple, fast and reliable. This method can be adopted by any researcher for their routine estimation. Further it is concluded that the absence of Bispyribac sodium in rice crop and soil substrate not pose any threat to the environment andany other commodities as it used in the recommended concentration.

\section{References}

[1] Tomar RAS. Encyclopedia of Agricultural Chemistry, New Delhi, Anmol Publications PVT. LTD. 2010; Vol. 1: pp. 1-20.

[2] M. Watts, Paraqu at Pesticide Action Network Asia \& the Pacific 2011. Retrieved from http://wssroc.agron.ntu.edu.tw/note/Paraquat.pdf.

[3] H. Muhamad, BS. Ismail, M. Sameni, N. Mat, Environ Monitor Assessment 49 (2010) 466-69.

[4] USDA Natural Resources Conservation Services. Understanding Soil Risks and Hazards: Using Soil Survey to Identify the Areas with Risks and Hazards to Human Life and Property 1998, Retrieved from:

http://www.nature.nps.gov/geology/soils/Understanding\%20Soil\%20Risks\%20and\%20H azards.pdf. 